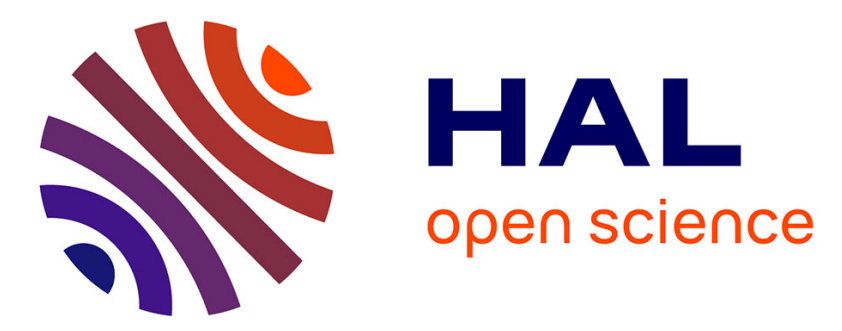

\title{
PHASE SPACE DYNAMICS OF HEAVY ION NUCLEAR COLLISIONS IN THE FERMI ENERGY DOMAIN
}

\author{
B. Remaud, C. Gregoire, F. Sebille, L. Vinet
}

\section{- To cite this version:}

B. Remaud, C. Gregoire, F. Sebille, L. Vinet. PHASE SPACE DYNAMICS OF HEAVY ION NUCLEAR COLLISIONS IN THE FERMI ENERGY DOMAIN. International Conference on Heavy Ion Nuclear Collisions in the Fermi Energy Domain Hicofed 86, 1986, Caen, France. pp.C4-99-C4-99, 10.1051/jphyscol:1986412 . jpa-00225775

\section{HAL Id: jpa-00225775 https://hal.science/jpa-00225775}

Submitted on 1 Jan 1986

HAL is a multi-disciplinary open access archive for the deposit and dissemination of scientific research documents, whether they are published or not. The documents may come from teaching and research institutions in France or abroad, or from public or private research centers.
L'archive ouverte pluridisciplinaire HAL, est destinée au dépôt et à la diffusion de documents scientifiques de niveau recherche, publiés ou non, émanant des établissements d'enseignement et de recherche français ou étrangers, des laboratoires publics ou privés. 


\title{
PHASE SPACE DYNAMICS OF HEAVY ION NUCLEAR COLLISIONS IN THE FERMI ENERGY DOMAIN
}

\author{
B. REMAUd, C. GRÉGOIRE*, F. SEBILle and L. VINET* \\ Institut de Physique, F-44072 Nantes Cedex, France \\ ${ }^{*}$ GANIL, BP 5027, F-14021 Caen Cedex, France
}

A decomposition of the nuclear one-body density distribution on a coherent state basis is shown to provide the adequate initial conditions for dynamical studies of heavy ion reactions /1-5/. The full three-dimension v1asov equation is solved and shows the transparency effects expected from pure mean field theories (see also the TDHF results quoted in ref. /7/). An extension of the vlasov equation (the LandauVlasov equation) by inclusion of a collision term - according to the UehlingUhlenbeck prescription - substancially reduces these transparency effects. The Landau-Vlasov equation describes a transition between the compound nucleus formation and the fragmentation-like reactions in the intermediate energy range. Linear momentum transfer exhibits a double-humped distribution. For peripherical reactions, at increasing incident energies, the model describes a process such as the correlation between the quasi-projectile and quasi-target masses could support an abrasion picture $16 /$. Such calculations allow to describe the relaxations of the momentum distributions and of the pressure tensors, which enlightens the equilibration processes in nuclear matter. Some of these results are illustrated in a film where the time evolution of density profiles for three typical reactions are displayed $/ 8 /$.

References :

/1/ C. GREgoIRE, B. REMAUd, F. SEBILLE, F. SCHEUTER, Nucl. Phys. A436 (1985) 365

/2/ B. Remaud, C. GRegoire, F. SEBiLle, L. Vinet, Nucl. Phys. A447 (1985) 555c

/3/ C. GREgOIRE, B. REMAUd, F. SEBILLE, L. VINET, P. SCHUCK, Trieste Meeting (1985)

/4/ L. VINET, F. SEBille, C. GREgOIRE, B. REMAUd, P. SCHUCK, Phys. Lett. B, in press

/5/ C. GREGOIRE, B. REMAUD, F. SEBILLE, L. VINET, preprint GANIL P86-05

/6/ R. DAYRAS et a1., NOUVELLES de GANIL 13 (1985)

/7/ J. AICHELIN, H. STOECKER, Phys. Lett. 163B (1985)59 and references therein. 18/ Heavy ion collisions in the intermediate energy domain (c) GANIL (1986) 